\title{
Comparative Analysis of Local Green Tea in Korea by STS-RFLP
}

\author{
Kiu-Hyung Cho ${ }^{1}$, Aruna Jo ${ }^{1,6}$, Tomohiko Tsuge ${ }^{2}$, Jong Cheol Kim ${ }^{3}$, Rumi Kim ${ }^{3}$, Ho-Sung Yoon ${ }^{4}$ \\ and Gyung-Tae Kim ${ }^{1,5 *}$
}

\author{
${ }^{1}$ Department of Molecular Biotechnology, Dong-A University, Busan 604-714, Korea \\ ${ }^{2}$ Institute for Chemical Research, Kyoto University, Uji, Kyoto 612-0011, Japan \\ ${ }^{3}$ Instutute of Hadong Green Tea, Gyeongnam 667-805, Korea \\ ${ }^{4}$ Department of Biology, Kyungpook National University, Daegu 702-701, Korea \\ ${ }^{5}$ Environmental Biotechnology Research Center, Gyeongsang National University, Jinju 660-701, Korea \\ ${ }^{6}$ Present address: Biotechnology Division, Korea Forest Research Institute, Suwon 441-350, Korea
}

Received August 24, 2010 / Accepted September 6, 2010

\begin{abstract}
Consumption of green tea has increased along with increasing concern regarding healthier lifestyles, and many brands of green tea are sold with a label indicating the region of Korea in which the tea was produced. However, there is little information on identifying the difference between the green tea cultivars according to the region they were grown. Here, 9 green tea cultivars collected from Hadong region, Bosung region, China and Japan were subjected to the STS-RFLP analysis. Using the coding and noncoding DNA regions of genes related to the phenylpropanoid pathway, such as phenylalanine ammonia-lyase, chalcone synthase and dihydroflavonol 4-reductase, we have identified the differences between green tea cultivars according to the region they were grown in. In this study, we showed a STS-RFLP method of green tea analysis which easily distinguished different kinds of tea using the primers as described. In addition, we identified that the green tea cultivars from Hadong and Bosung displayed a different profile when PAL intron was digested with Dde I, suggesting that a rapid authentication system for green tea cultivars grown in different regions in Korea is available.
\end{abstract}

Key words : Green tea, STS-RFLP, CAPS, polymorphism

\section{서 론}

차나무(Camelia sinensis (L.) O. Kuntze)는 목본성 관목식물 로, 차는 주로 아시아 지역에서 생산되고 전세계에서 물 다음 으로 많이 소비되는 음료이다. 아시아 지역에서는 차나무가 수 천년 동안 음료의 목적으로 재배되어 왔으며, 최근 항암 (anticarcinogenic), 항산화(antioxidant), 항균성(antibacterial) 과 같은 차의 특성이 알려지면서 그 생산량은 꾸준히 증가하 고 있는 추세이다[7]. 많은 한국의 역사문헌들에 의하면 차나 무 씨앗이 9세기 초 중국(Tang Dynasty)으로 부터 국내에 도 입되었으나 12세기까지는 상업적으로 재배되지 않았다[2]. 일 본의 차 도입은 한국과 비슷한 시기에 이루어진 것으로 보고 되어 있으며[9], 현재 대부분의 일본의 재배 품종이 중국과 일 본에서 유래되었고 개량되었다고 알려지고 있다[2,6]. 한편, 한 국에서 재배되고 있는 상업적인 품종에 대해서는 두 가지 부 류로 구분할 수 있는데, 한 부류는 야생차로부터 유래되어온 재배품종이고, 다른 한 부류는 일본에서 들여온 개량품종에서 유래한 것이다. 따라서 앞으로 국내 재배차의 품종구분 및 품 질관리를 위해서 이들의 구별법을 연구할 필요가 있다고 사료

*Corresponding author

Tel : +82-51-200-7519, Fax : +82-51-200-7524

E-mail : kimgt@donga.ac.kr
된다.

지금까지 안토시아닌 생합성 경로인 페닐프로파노이드 (Phenylpropanoid) 합성경로에 관련된 phenylalanine ammonia-lysate (PAL), chalcone synthase (CHS), dihydroflavonol 4-reductase (DRF) 등의 유전자가 녹차에서 clone되었고[5,8], 녹차 의 분자마커로 이들 유전자를 이용한 CAPS 마커가 개발되어 $[3,4]$, Sequence Tagged Site-Restriction Fragment Length Polymorphism (STS-RFLP)법을 이용하여 일본에서 판매되는 46종의 녹차 브랜드의 polymorphism 패턴을 분석을 시도하 였다 $[3,4]$. 한국에 토종 야생 녹차가 존재하는지에 관한 논쟁의 여지는 있으나, 이전 연구를 통하여 우리들은 지금까지 알려 져 있지 않은 지리산 근처(하동 지역)에 자생하고 있는 야생차 군집의 유전적 배경(genetic background)를 분석하여 야생녹 차 군집과 재배녹차의 다양한 유전자 자원(genetic resources) 을 비교분석 하였다[1]. 그 결과로 국내에 야생녹차 군집은 중 국과 일본의 재배품종과는 다른 기원(origin)에서 진화되었다 는 사실을 밝혔다[1].

한국의 차는 전라도, 경상도 그리고 제주도에서 주로 재배 되고 있으며, 그 중에서도 전라남도 보성과 경상남도 하동의 지리산 부근의 차 재배면적이 가장 넓은 것으로 알려져 있다. 여기서 재배되고 있는 녹차의 명칭은 특정 품종 이름이 아닌 재배 지역의 이름으로 판매되고 있다. 아직까지 이들 지역에 
서 재배되고 있는 녹차품종이 명확하게 밝혀져 있지 않고, 이 들 지역적으로 재배되는 차의 품종을 구별할 방법은 아직 확 립되어 있지 않다.

본 연구에서는 확립되어진 STS-RFLP법을 이용하여 각 지 역 녹차의 polymorphism 패턴을 확립함으로써, 지금까지 명 확하게 알려져 있지 않은 지역 간 녹차의 품종을 구별하여 국내 녹차의 인증에 사용할 수 있는 방법을 제시하고자 한다.

\section{재료 및 방법}

\section{식물재료}

실험에 이용된 재료는 차나무(var. sinensis)에서 수집한 신 선한 잎을 사용하였으며, 하동지역 5종류(야생 천년녹차, 야생 녹차, 시배지녹차, 2 종류의 재배녹차), 보성 지역에서 1 종류(재 배녹차)를 선발하였다. 한국 야생녹차 군집의 유전적 다양성 분포를 결정하기 위하여 중국에서 1 종의 재배녹차인 용정차 (Longjing), 일본에서 2종류의 재배녹차(Yabukita, Tsukigase) 를 선발하여 비교 분석하였다. 하동 야생 천년 차나무는 수령이 800 년 된 것으로 국내에서는 현재까지 알려진 최고령 차 나무이 며, 하동 야생녹차 군집은 지리산 저지대의 $20 \mathrm{~m}^{2}$ 에 분포한 것 을 수집하였고, 하동 시배지녹차는 보다 넓은 $500 \mathrm{~m}^{2}$ 지역에 분포한 것을 수집하였다. 보성 지역 녹차는 지역 재배 농장에 서 수집되었다. 중국차 용정차는 중국 항저우(Hangzhou)의 녹 차 농장에서 수집되었으며, 일본 차는 Tsukigase와 국내에서 상업적 생산을 위하여 주로 재배한다고 알려진 Yabukita를 일본 교토(Kyoto)의 Ujitawara에 있는 한 농장으로부터 수집 하여 사용하였다.

\section{$\mathrm{PCR}$ 및 제한효소 처리 산물의 분석}

실험에 사용된 녹차의 게놈 DNA는 DNeasy Plant Kit (QIAGEN, Hilden, Germany)을 사용하여 싱싱한 녹차 잎으 로부터 추출되었다. 각각의 녹차 잎은 액체질소를 첨가한 후
에 막자사발을 이용하여 가늘게 분쇄하였으며, 가늘게 분쇄된 녹차 잎으로부터 $100 \mathrm{mg}$ 의 녹차 잎이 1 회 추출에 사용되었다. 추출 방법은 제조사에서 제공한 매뉴얼을 따라 수행되었다. $\mathrm{PCR}$ 은 최종 볼륨 $25 \mu \mathrm{l}$ 으로 수행되었으며, 게놈 DNA는 $50-100 \mathrm{ng} / \mu \mathrm{l}$, 프라이머는 각각 $0.5 \mu \mathrm{M}$ 씩, dNTP는 $200 \mu \mathrm{M}$ 씩 사용하여, 0.5 unit의 ExTaq polymerase (Takara, Shinga, Japan)을 이용하여 BIO-RAD thermocycler modle iCycler (Bio-Rad, Hercules, CA)에서 수행되었다. PCR 조건은 $94^{\circ} \mathrm{C}$ 에 서 5 분간 초기의 denaturation step을 수행한 후 $94^{\circ} \mathrm{C}$ 에서 30 초, $60^{\circ} \mathrm{C}$ 에서 1 분, $72^{\circ} \mathrm{C}$ 에서 1.5 분을 순서대로 32 cycle 반복했 으며 최종 elongation step을 $72^{\circ} \mathrm{C}$ 에서 10 분간 수행하였다. STS-RFLP법에 사용된 PCR 프라이머는 Table 1 [4]에 기술하 였다. RFLP분석을 위하여 $3 \mu \mathrm{l}$ 의 PCR 산물을 사용하여 Table 1에 서술된 제한효소(Takara, Shiga, Japan; BioLab, USA)를 이용하여 절단하였다. 제한효소처리를 위한 처리온도로는 $\mathrm{Taq} \mathrm{I}$ 를 $65^{\circ} \mathrm{C}$ 에서 반응시킨 것을 제외하고는 모든 제한효소는 $37^{\circ} \mathrm{C}$ 에서 반응되었다.

\section{결과 및 고찰}

\section{하동 지역 녹차와 보성 지역 재배 녹차 및 중국 일본 품종 의 유전자 polymorphism 패턴 비교분석}

우리는 이전 연구를 통하여 한국에 현재 야생으로 자생하는 녹차가 일본 녹차와는 다르게 진화해 왔으며, 지리산 부근(하 동 지역)에 자생하고 있는 야생녹차 군집은 일본 녹차와는 다 른 독특한 유전자형을 가지고 있었으며 중국과 일본의 재배품 종과는 다른 기원(origin)에서 진화되었다는 사실을 밝혔다 [1]. 그러나 국내 녹차가 재배 지역의 품종에 따라 polymorphism 패턴의 차이가 보이는지, 어디서 기원되었는지에 관하여는 아직 연구되어 있지 않다. 본 연구에서는 이전 연구 결과를 바탕으로 국내 하동지역과 보성지역의 재배 녹차품종 의 polymorphism 패턴을 분석하여 지역 재배 녹차의 품종을

Table 1. PCR primer restriction enzymes used for STS-RFLP analysis

\begin{tabular}{|c|c|c|}
\hline Amplified regions & Primers & Restriction enzymes \\
\hline \multicolumn{3}{|l|}{ For CAPS analysis } \\
\hline \multirow[t]{2}{*}{ PAL exon I } & 5'-TCCATCAATCTATACACCTACCTG-3' & Hpa II \\
\hline & 5'-CСТTCTTTGGTCCTCCTATGTGA-3' & \\
\hline \multirow[t]{2}{*}{ PAL intron } & 5'-CACATAGGAGGACCAAAGAAGG-3' & Dde I \\
\hline & 5'-GGCAATGGTAAGATAGGGGGACT-3' & \\
\hline \multirow[t]{2}{*}{ PAL exon 2} & 5'-AGTCССССТАТСТTACATTGCC-3' & Taq I \\
\hline & 5'-ATAGAAGAAACCAAGCCGGAAC-3' & \\
\hline \multirow[t]{2}{*}{ CHS exon 2} & 5'-AAACCCAAATGTGTGTGCCTAC-3' & Bsp HI, Rsa I \\
\hline & 5'-AGGATAAACAACACACAAGCGC-3' & \\
\hline \multirow[t]{2}{*}{ DFR intron 3} & 5'-CCAGGAACACCAACAACCCGT-3' & Hind III \\
\hline & 5'-CCATGCTGCTTTCTCTGCCAA-3' & \\
\hline \multirow[t]{2}{*}{ DRF intron $4+5$} & 5'-AACATTCCСACCAAGCCTAATC-3' & Hpa II \\
\hline & 5'-ATGAGAACGACACAACTGGCAA-3' & \\
\hline
\end{tabular}


구별할 수 있는지에 대한 실험을 시도하였다. 우선 분석을 위 한 재료로 하동지역에서 재배녹차 2 품종을, 보성지역에서 재 배녹차 1품종을 채집하여 사용하였고, 비교를 위해서 하동지 역에서 가장 오래되었다는 하동 천년녹차, 시배지녹차를 대조 구로 사용하였다. 그리고, 국내와 국외 녹차 품종의 차이를 비교 하기 위하여 중국의 재배녹차로 용정차를, 일본에서 2종류의 재배녹차 품종(Yabukita와 Tsukiagse)을 선발하여 사용하였 다. Yabukita는 일본 중국에서 차를 도입한 후에 Shizuoka에 서 재배종으로 개량육종한 유명한 녹차품종이며 국내에서도 상업적인 생산을 목적으로 많은 재배면적을 차지하는 주요 품종이기에 비교를 위해서 사용하였다. 페닐프로파노이드 생 합성과 관련된 PAL, CHS 그리고 DFR 유전자는 식물 종마다 염기서열이 잘 보존되어 있을 뿐만 아니라 이들 유전자를 이 용한 CAPS 마커가 잘 개발되어 왔고[4,5,8], 지역 녹차의 polymorphism을 구별하기 위해 table 1에 서술된 프라이머를 이 용하여 3 개 유전자의 6 종류의 PCR산물을 6 종류의 제한효소 로 사용하여 처리한 STS-RFLP를 수행하였다(Fig. 1).

조사한 총 9종류의 녹차품종 전부에서 벤드 크기 및 패턴에 있어서 서로 다른 polymorphism 패턴을 보였다(Fig. 1). 이전 에 수행된 46 종류의 재배 녹차[3]와 비교 분석한 결과, 조사한 품종이 앞서의 46종류와 일치하는 품종이 하나도 없는 것으로
판명이 되었다. 이는 이전의 연구결과와 마찬가지로 본 연구 에 사용한 CAPS 마커만으로도 녹차품종을 구별할 수 있다는 사실이 판명되었다. 특히 $P A L$ intron 영역을 제한효소 $D d e$ I으로 절단하였을 때(Pint/D) 하동 지역 재배녹차에서는 $\mathrm{A}_{1} \mathrm{~B}$ (하동재배차 1 ), $\mathrm{A}_{1} \mathrm{~A}_{1}$ (하동재배차2)의 polymorphism 패턴을 보였으며, $P A L$ exon2 영역을 $T a q$ I으로 절단하였을 경우 $(\mathrm{P} 2 / \mathrm{T})$ 와 CHS exon 2 를 Rsa I으로 절단한 경우(C2/R)에서도 $\mathrm{AB}$ (하동재배차1)와 $\mathrm{AA}$ (하동재배차2)로 다르게 나타났으며, 이를 제외한 나머지 CAPS 마커는 서로 일치함을 보였다(Fig. 1 and Table 2). 이 사실로 하동 재배녹차 1 과 하동 재배녹차 2 는 서로 같은 계통으로부터 파생되어 나왔으며 교잡을 통해서 잡종화 된 것으로 보여진다. 가장 오래된 차나무라고 알려지 고 있는 하동 천년녹차(경남 하동소재)와 우리나라에서 녹차 를 생산하기 위하여 처음 재배가 되었던 하동 시배지녹차(경 남 하동소재)는, PAL exon 영역을 Hpa II로 절단하였을 경우 $(\mathrm{P} 1 / \mathrm{H})$ 와 $\mathrm{CHS}$ exon 2를 Bsp HI으로 절단한 경우(C2/B)에서 각각 $\mathrm{BB}, \mathrm{BB}$ 로 같은 패턴을 보였을 뿐 나머지 5 개 마커는 서로 다른 패턴을 보였다(Fig. 1 and Table 2). 이 결과는 한 지역에 서 오래 고착되어 살아온 하동 야생 천년녹차와는 다르게 하 동 시배지녹차는 오랜 세월동안 많은 교잡을 통하여 잡종화되 었음을 시사하고 있다. 또한 하동지역에 야생으로 자생하고
A

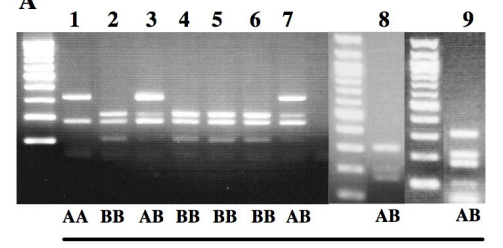

P1 / H

D

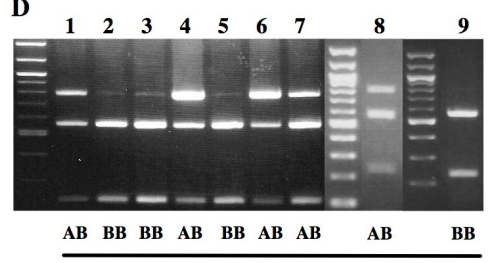

C2 / B

G

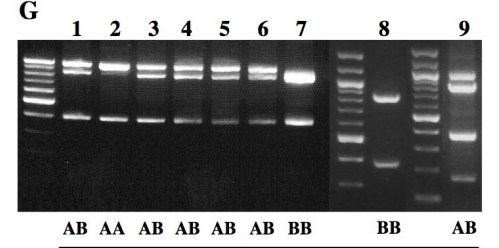

D4 / H

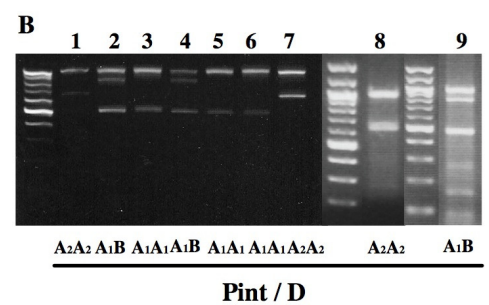

Pint / D

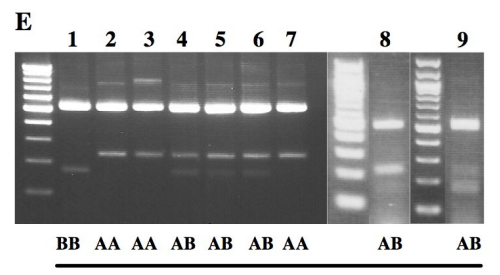

$\mathbf{C 2} / \mathbf{R}$

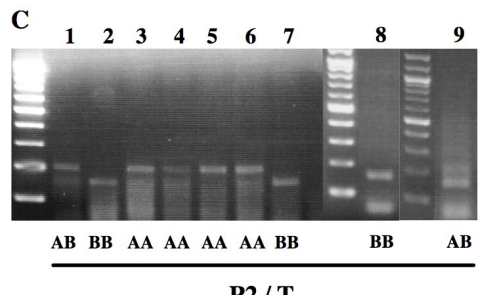

$\mathbf{P 2} / \mathbf{T}$

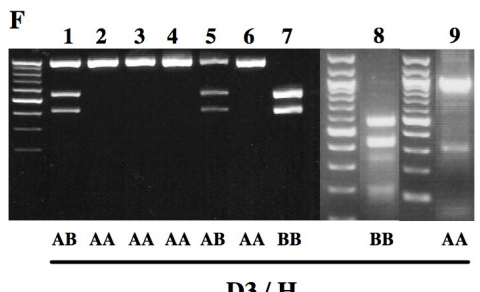

$\mathbf{D 3} / \mathbf{H}$

Fig. 1. The polymorphism patterns of Korean (Hadong and Bosung), Japanese and Chinese green teas in STS-RFLP analyses. P1/H (A), Pint/D (B), P2/T (C), C2/B (D), C2/R (E), D3/H (F) and D4/H (G) indicate PAL exon1/Hpa II, PAL intron/Dde I, PAL exon 2/Taq I, CHS exon 2/BspH I, CHS exon 2/Rsa I, DFR intron 3/Hind III and DFR intron 4+5/Hpa II. AA, $A B, B B, A_{1} A_{1}, A_{1} A_{2}, A_{2} A_{2}$ and $A_{1} B$ indicate the polymorphism pattern of the analyzed tea plants. Lanes from 1 to 9 are Bosung tea, Hadong Sibaeji tea, Hadong cultivar 2, Hadong wild tea, Hadong Cheon-nyeon wild tea, Longjing cultivar, Tsukigase, Yabukita and Hadong cultivar 1, respectively. 
Table 2. The polymorphism patterns of Korean (Hadong and Bosung), Japanese and Chinese green teas in STS-RFLP analyses

\begin{tabular}{lccccccc}
\hline & \multicolumn{3}{c}{ CAPS markers } \\
\cline { 2 - 7 } & $\mathrm{P} 1 / \mathrm{H}$ & Pint/D & $\mathrm{P} 2 / \mathrm{T}$ & $\mathrm{C} 2 / \mathrm{B}$ & $\mathrm{C} 2 / \mathrm{R}$ & $\mathrm{D} 3 / \mathrm{H}$ & $\mathrm{D} 4 / \mathrm{H}$ \\
\hline Hadong cheon-nyeon wild tea & $\mathrm{BB}$ & $\mathrm{A}_{1} \mathrm{~A}_{1}$ & $\mathrm{AA}$ & $\mathrm{BB}$ & $\mathrm{AB}$ & $\mathrm{AB}$ & $\mathrm{AB}$ \\
Hadong wild tea & $\mathrm{BB}$ & $\mathrm{A}_{1} \mathrm{~B}$ & $\mathrm{AA}$ & $\mathrm{AB}$ & $\mathrm{AB}$ & $\mathrm{AA}$ & $\mathrm{AB}$ \\
Hadong sibaeji tea & $\mathrm{BB}$ & $\mathrm{A}_{1} \mathrm{~B}$ & $\mathrm{BB}$ & $\mathrm{BB}$ & $\mathrm{AA}$ & $\mathrm{AA}$ & $\mathrm{AA}$ \\
Hadong cultivar 1 & $\mathrm{AB}$ & $\mathrm{A}_{1} \mathrm{~B}$ & $\mathrm{AB}$ & $\mathrm{BB}$ & $\mathrm{AB}$ & $\mathrm{AA}$ & $\mathrm{AB}$ \\
Hadong cultivar & $\mathrm{AB}$ & $\mathrm{A}_{1} \mathrm{~A}_{1}$ & $\mathrm{AA}$ & $\mathrm{BB}$ & $\mathrm{AA}$ & $\mathrm{AA}$ & $\mathrm{AB}$ \\
Bosung tea & $\mathrm{AA}$ & $\mathrm{A}_{2} \mathrm{~A}_{2}$ & $\mathrm{AB}$ & $\mathrm{AB}$ & $\mathrm{BB}$ & $\mathrm{AB}$ & $\mathrm{AB}$ \\
Longing cultivar & $\mathrm{BB}$ & $\mathrm{A}_{1} \mathrm{~A}_{1}$ & $\mathrm{AA}$ & $\mathrm{AB}$ & $\mathrm{AB}$ & $\mathrm{AA}$ & $\mathrm{AB}$ \\
Yabukita & $\mathrm{AB}$ & $\mathrm{A}_{2} \mathrm{~A}_{2}$ & $\mathrm{BB}$ & $\mathrm{AB}$ & $\mathrm{AB}$ & $\mathrm{BB}$ & $\mathrm{BB}$ \\
Tsukigase & $\mathrm{AB}$ & $\mathrm{A}_{2} \mathrm{~A}_{2}$ & $\mathrm{BB}$ & $\mathrm{AB}$ & $\mathrm{AA}$ & $\mathrm{BB}$ & $\mathrm{BB}$ \\
\hline
\end{tabular}

P1/H, Pint/D, P2/T, C2/B, C2/R, D3/H and D4/H indicate PAL exon1/Hpa II, PAL intron/Dde I, PAL exon 2/Taq I, CHS exon 2/Bsp HI, CHS exon 2/Rsa I, DFR intron 3/Hind II and DFR intron4+5/Hpa II. AA, AB, BB, $\mathrm{A}_{1} \mathrm{~A}_{1}, \mathrm{~A}_{1} \mathrm{~A}_{2}, \mathrm{~A}_{2} \mathrm{~A}_{3}$ and $\mathrm{A}_{1} \mathrm{~B}$ indicate the polymorphism pattern of the analyzed tea plants.

있는 하동 야생녹차를 분석한 결과, polymorphism 패턴이 하 동 시배지녹차와 가장 가깝게 나타나 $\mathrm{P} 1 / \mathrm{H}, \mathrm{Pint} / \mathrm{D}$, 그리고 $D R F$ intron 3 영역을 Hind III로 절단한 패턴 $(\mathrm{D} 3 / \mathrm{H})$ 만 각각 $\mathrm{BB}, \mathrm{A}_{1} \mathrm{~B}$, 그리고 $\mathrm{AA}$ 로 같았고, 나머지 4 개 마커는 다른 패턴을 보였다(Fig. 1 and Table 2). 또한 하동 야생차는 P1/H, PAL exon 2를 Taq I으로 절단한 경우(P2/T), C2/R, 그리고 $D F R$ intron $4+5$ 를 $\mathrm{Hpa}$ II로 절단한 경우 $(\mathrm{D} 4 / \mathrm{H})$ 에서 하동 야생 천 년녹차와 같은 패턴을 보였으며, 나머지 3개 마커의 경우 다르 게 나타났다(Fig. 1 and Table 2). 하동 재배녹차도 3개의 마커 가 하동 야생녹차와 비슷한 패턴을 보였다. 이들의 결과는 하 동 야생녹차, 하동 야생 천년녹차, 그리고 하동 시배지녹차는 많은 부분에서 비슷한 패턴을 보인 것으로 보아 같은 계통으 로부터 파생되어 나왔을 가능성이 높을 것으로 보여진다.

비교를 위해서 사용한 일본품종 Yabukita와 Tsukigase는 $\mathrm{C} 2 / \mathrm{R}$ 의 패턴이 각각 $\mathrm{AB}$ 와 $\mathrm{AA}$ 로 다르게 나타났을 뿐 다른 6 개 마커의 패턴은 같은 것으로 판명되었으며, Tsukigase는 Yabukita로부터 개량된 비슷한 계통이라는 사실을 알 수 있 다. 이들과 하동 재배녹차는 $\mathrm{P} 1 / \mathrm{H}$ 와 $\mathrm{C} 2 / \mathrm{R}$ 의 두 마커에서만 같은 패턴을 보였을 뿐, 나머지는 서로 다른 패턴을 보였다. 따라서, 하동 재배녹차는 일본품종과는 기원이 다를 가능성이 높다고 생각되어진다. 중국의 대표적인 녹차품종으로 용정차 (중국 항저우 채집)는 하동 야생 천년녹차와 가장 비슷한 패턴 을 보였으며, 이는 비슷한 계통에서 유래되었을 가능성을 시 사하고 있다.

한편, 보성지역에서 재배되고 있는 보성 재배녹차는 하동 재배녹차와는 $\mathrm{P} 2 / \mathrm{T}(\mathrm{AB}$, 하동 재배녹차 1$)$ 과 $\mathrm{D} 4 / \mathrm{H}(\mathrm{AB}$, 하동 재배녹차 1,2$)$ 에서 같은 패턴을 보였지만 나머지 5 개 마커의 패턴은 다르게 나타났다. 따라서 보성 재배녹차와 하동 재배 녹차는 서로 다른 품종(또는 차나무)에서 유래되었을 가능성 이 제시되었고, $\mathrm{CHS}$ 유전자의 마커만 사용하더라도 서로 구 별할 수 있다는 사실이 판명되었다(Fig. 1). 하지만, 하동 재배 녹차와 마찬가지로 보성 재배녹차도 일본 품종들과는 많은
부분에서 다르게 나타났고, 용정차와도 많이 다른 패턴을 나 타내었기에 일본과 중국의 대표적 품종과는 뚜렷이 구별할 수 있는 마커로 사용 가능한 것으로 판명 되었다.

이 연구에서는 STS-RFLP법을 이용하여 국내 지역 재배녹 차의 품종간 차이를 분석하였으며, 결과를 바탕으로 지역에서 재배되는 녹차를 인증하는 방법으로 CAPS 마커를 사용한 프 로토콜을 제공하였다. 이는 일본과 중국의 대표적 품종과 구 별될 수 있는 마커를 제공함과 동시에, 국내 지역의 품종간의 브랜드 가치를 높이는데 기여할 것으로 사료된다. 하지만 이 들 품종의 기원이 어디서부턴지 어떻게 진화의 과정을 거쳤는 지를 밝히기는 본 연구만으로는 어렵다고 사료된다. 다만 국 내 재배품종이 어느 기원에서 유래가 되었는지는 모르지만 이들이 타가수분에 의한 자연적인 수정(또는 인위적인 교배) 으로 국내 지역에서 hybrid상태의 품종으로 재배, 생산되고 있다는 사실을 본 연구에서 알 수 있다. 앞으로 체계적인 계통 분석을 통하여 국내 재배품종과 야생차의 기원과 진화에 대한 궁금증을 풀 수 있을 것으로 기대된다.

\section{감사의 글}

이 논문은 정부재원(교육인적자원부 학술연구조성사업비) 으로 학술진흥재단의 지원을 받아 연구되었음(KRF-2008-359F00003, K.-H. C.), (KRF-2006-321-C00671, G.-T. K.). 또한, 본 논문은 농촌진흥청 바이오그린21사업(과제번호: 20070301034-037)의 지원에 의해서 이루어진 것임.

\section{References}

1. Cho, K. H., E. J. Lee, A. Jo, J. C Kim, G. W. Cheng, H. S. Yoon, and G. T. Kim. 2010. Comparative genomic analysis of Korean and Japanese green teas by using molecular markers. Can. J. Plant Sci. 90, 293-298. 
2. Choi, H. K. 2000. Tea breeding and cultivation in Korea. J. Korean Tea Soc. 6, 121-137.

3. Kaundun, S. S. and S. Matsumoto. 2003a. Identification of processed Japanese green tea based on polymorphisms generated by STS-RELP analysis. J. Agric. Food Chem. 51, 1765-1770.

4. Kaundun, S. S. and S. Matsumoto. 2003b. Development of CAPS markers based on three key genes of the phenylpropa- noid pathway in Tea, Camellia sinensis (L). O. Kuntze, and differentiation between assamica and sinensis varieties. Theor. Appl. Genet. 106, 375-383.

5. Matsumoto, S., A. Takeuchi, M. Hayatsu, and S. Kondo. 1994. Molecular cloning of phenylalanine ammonia-lyase cDNA and classification of varieties and cultivars of tea plants (Camellia sinensis) using a tea pal cDNA probe. Theor. Appl. Genet. 89, 671-675.
6. Matsumoto, S., Y. Kiriiwa, and Y. Takeda. 2002. Differentiation of Japanese green tea cultivars as revealed by RFLP analysis of phenylalanine ammonia-lyase DNA. Theor. Appl. Genet. 104, 998-1002.

7. Siddiqui, I. A., V. M. Adhami, M. Saleem, and H. Mukhtar. 2006. Beneficial effects of tea and its polyphenols against prostate cancer. Mol. Nutr. Food Res. 50, 130-143.

8. Takeuchi, A., S. Matsumoto, and M. Hayatsu. 1994. Chalcone synthase from Camellia sinensis: isolation of the cDNA and the organ-specific and sugar-responsive expression of the genes. Plant Cell Physiol. 35: 1011-1018.

9. Yamaguchi, S., S. Matsumoto, and J. Tanaka. 1999. Genetic dispersal of tea plant. pp. 413-426, In Jain, N. K. (ed.), Global advances in tea science. Aravali Books International, New Delhi, India.

\section{초록 : STS-RFLP법을 이용한 국내지역 재배녹차의 비교분석}

조규형 ${ }^{1} \cdot$ 조아르나 ${ }^{1,6} \cdot$ Tomohiko Tsuge $^{2} \cdot$ 김종철 ${ }^{3} \cdot$ 김루미 ${ }^{3} \cdot$ 윤호성 ${ }^{4} \cdot$ 김경태 ${ }^{1,5 *}$

( ${ }^{1}$ 동아대학교 분자생공학부, ${ }^{2}$ 교토대학교 화학연구소, ${ }^{3}$ 하동녹차연구소, ${ }^{4}$ 경북대학교 생물학과, ${ }^{5}$ 경상대학교 환경생명과학연구센터, ${ }^{6}$ 국립산림과학원)

최근 웰빙 열풍으로 나날이 녹차에 대한 관심과 소비가 증가하고, 생산 재배되고 있는 산지에 대한 브랜드화가 진행되고 있다. 하지만 지역에서 재배되고 있는 녹차품종의 구별 및 차이에 대해서는 아직 많은 연구가 되어 있 지 않고 있다. 이 연구에서 국내 대표 녹차산지인 하동지역과 보성지역에서 채집한 녹차와 중국과 일본의 대표적 녹차품종을 가지고 STS-RFLP분석을 수행하였다. 페닐프로파노이드 생합성 경로에 관여하는 페닐알라닌 암모니 아 리아제와 찰콘 합성효소 그리고 디하이드로플라보놀 4-리덕타아제 유전자의 암호영역과 비암호영역을 사용하 여 이들 품종들을 구별할 수 있는 연구에 성공하였다. 이 논문에서는 녹차품종 구별에 사용 가능한 STS-RFLP법 과 프라이머를 나타내었고, 하동지역과 보성지역의 녹차품종을 CHS 유전자의 CAPS 마커만으로 구별할 수 있는 방법을 찾아내어, 국내 지역간 품종의 구분 및 검증에 사용할 수 있다는 사실을 제시하였다. 